\title{
フィルム，膜の科学
}

\section{稲 垣訓宏}

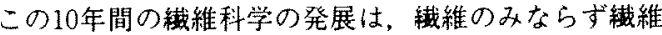
と深く関連する新しい学問分野の重要さを認識させた。 膜の科学も瀻維科学の発展によって生まれたものであ る。従来，この分野の研究成果は擮䌖学会の年次大会研 究発表会の一つの発表部門として取り扱われていたが， 1985年に䄉維学会の年次大会研究発表会加独立して

「膜一その基礎科学と技術一に関する」シンポジウムと して今日に至っている。このシンポジウムは本年でちよ うど10回を数えるが，今回のレビューではこのシンボジ ウムを中心に述べることとする。

「膜一その基礎科学と技術一に関する」シンポジウム は，膜分離の物理科学，膜の構造と機能，膜のシステム 工学に加之，物質分離，促進輸送，能動輸送，刺激応 答，情報記録などの機能付与する薄膜化をも包含する広 以分野での研究成果を発表し，研究者の情報交换する場 を提供するものとして，1985年に発足した。このシンポ 济么の発足は，阪大・小高教授、東工大·小見山教 授, 谷岡助教授, 名工大・过田教授、東レ・栗原氏, ダ イゼル・中西氏らの多大の尽力の結果である。現在は, 発足時の6人の実行委買の他に，静岡大・稻垣が加わっ ている。昨年までに 9 回のシンポジウムが開催されてい ろが，その中で第 3 回(1987)と第 8 回(1992)シンポジウ 么は国際シンポジウムと名をうち，海外からの第一線の 研究者を招聘して開催している。この研究者の招聘には 緎維学会宮崎基金の援助を受けた。

シンポジウムはその年の膜分野でトピックスとなって いるテーマに造詣の深い研究者による招待講演と一般公 募の研究発表の 2 つ形式によって構成されている。第 8 回のシンポジウムからは, 一般公募の研究発表の件数 が增えたため会場の手当てが苦しくなったこと，ざらに 十分な研究者間の討議をする時間を確保するため，ポス 夕一形式での発表形式に変えている。招待講演の題目を 朓めてみると，その時の関心事が何であったかを振り返 ることができ，膜科学の発展の道筋をたどることができ る。表 1 は招待講演の講演題目と講演者をまとめたもの である。

図1は9回のシンポジウムに一般から応募された研究発
表件数をまとめたものである。なお、これらの研究発表 の内容老 1 ) 膜合成，2）透過機構，3）膜の機能, 4) 分離プロセスの4つの分野に大別してある。第 1 回 のシンポジウムを除いて，毎回20-30件の研究発表がな されで扔り、このシンポジウムが膜科学の重要な研究発 表の場を提供していることがわかる。4つの分野に大別 した研究発表の割合は図 2 に示したが, シンポジウムを 重ねるにしたがって，研究発表の分野が推移している。 合成膜，ポリペプチド膜，LB膜などの膜を作成する素 材の合成 (膜合成分野に分類) は，今でも膜科学の重要 なテーマであるが初期のころの研究の势いは見られな い。これに代わって，ガス・液体・イオンなどの分離機 能，膜を介する電気・電子機能を追求した分野（膜の機 能に分類），分噰プロセスを追求した分野（分離プロセ スに分類）に研究が移行している傾向が読み取れる。

膜合成分野は図 3 に見られるように，合成高分子膜， ポリペブチド膜，LB，二分子膜，グラフトなどの改質 手法を駆使した膜改質と，その他に分けたが，ポリペプ チド，膜改質による膜合成が多い。エチレングリコー ル、オリゴシロキサンなどの特異な側鎖基を結合したポ リグルタメート膜の合成（名工大），ブラズマ重合，プ ラズマ処理を用いた新規膜の合成（静岡大）らは毎年研 究成果が報告されている。

透過機椪分野は，収着・搪散，分子鎖運動，膜の高次 構造に分けたが，分離機構を解明する収着・拡散を取り 扱ったものが断然多い（图 4 参照）。荷電膜における透 過挙動（東工大），炭酸ガスならびに有機ガスの収着举 動（物質工学工業技術研究所），LB 膜の凝集構造（九 大）などは毎年継続的に與味深い研究成果が発表されて いる。

膜機能は年々研究成果が増加している部門である。こ の分野での研究の動向は，図 5 に示した膜機能の分類か らうかがい知ることができる。ガス分離, 液体分離、 イ オン分離に加え，最近特に膜の電気・電子機能を追求し た研究が貽味を持たれている。アミンを含有した二酸化 炭素分離膜 (京都工䄉大)，キシレン異性体の分離膜 (関西大)，ポリグルタミン酸のイオン選択透過膜（東 
表 1 シンポジウムの招待講演リスト

第 1 回（1985）シンポジウム

・膜の医療への応用（旭メディカル）須磨靖德

・膜の不均一吸着掠よび拡散 (東工大工) 飯島俊郎

第 2 回 (1986) シンポジウム

・分子認識機能膜（筑波大・東工大）相沢益男

・高効率分離膜研究の現状（製科研）山田純男

第 3 回（1987）シンポジウム

·二次元蛋白質結晶に上る等孔径多孔質限外滤過膜の構造と特性 (ウィーン農科大学) Nargit Sara

・コンポジェットイオン交換膜 (ワイッマン研) Ora Kedem A. Warshawsky

・物質分離のための新しい合成膜（マックスプランク生物物理研）Wolfgang Pusch

第 4 回（1988）シンポジウム

・合成膜による新しい分離機能の発現（神奈川大工）井川 学

・人口膜による生体機能の代行一人工腎臟を例として (丹沢ラボ) 丹沢 厷

第 5 回 (1989) シンポジウム

・エネルギー变換生体膜の分子生物学（自治医大）香川靖雄

・液体混合物のパーベーパレーション分離膜（三井造船）浅田敏雄

第6 回（1990）シンポジウム

・プラズマ重合膜の形成とその応用（茨城大，教養）長田義仁

·酸素透過膜開発の現状について（松下技研）浅川史朗

・膜分㒕技術の最近の展開（䄉高研）溝口健作

第 7 回 (1991) シンポジウム

・ポルフィリン錯体膜による酸素輸送（早大，理工）西出宏之

・高分子分離膜の溶質透過性と微細構造（高分子基盤技術組合）藤井能成

・アフィニティ膜システムによるバイオプロセッシング (栗田工業) 木村硯敏

第 8 回 (1992) シンポジウム

- Transport Phenomena across Charged Polymer Membranes: Problem in Amphoteric Solutes and Polymers

(Tokyo Inst. of Technol.) A. Tanioka

- Better Hollow Fiber Contactors (Univ. of Minnesota) E. L. Cussler

- Ube's Developments in Industrial Gas Separation Membranes (Ube Kosan Co.) S. Ono

- Fine Structure of a Porous Polymeric Membranes and its Performance (Asahi Kasei Chem. Ind. Co.)

S. Manabe

- Molecular Interpretation of Diffusion Process in Membranes (3M Corp., Res. Lab.) L. A. Errede

- Permeation of Small Molecules and Structure Properties of Polymeric Membranes (Nagoya Inst. of Technol.)

Y. Tsujita

- Low Temperature Plasma Treatment and Plasma Polymerization for Membrane Technology

(Univ. of Missouri-Columbia) H. Yasuda

第 9 回（1993）シンポジウム

·分離膜素材としてのポリイミドフィルム（明治大，工）仲川 勤

・静電場印加法による機能性複合膜の調製（福井大，工）中村良治

·分蜼膜と環境問題 (東レ) 植村忠廣

・高分子膜ガスバリヤー性と包装（東洋製缶グループ綜研）平 和雄

工大）の研究は継続的に続けられてきた。これらの機能

に加え，この数年は膜電位からの基犋認識（明治大）,

電子伝達の機能を持つ膜（福井大，東工大），アミノ酸

の光学分割 (明治大)，ガスセンサー素子(静岡大) な
どの新しい機能への取組が見られる。

溶質分蜼のための膜塔の試作（物質工学工業技術研究 所），地下水污染浄化のための分離膜開発（物所工学工 業技術研究所）なと膜を用いた分離プロセスへの関心も 


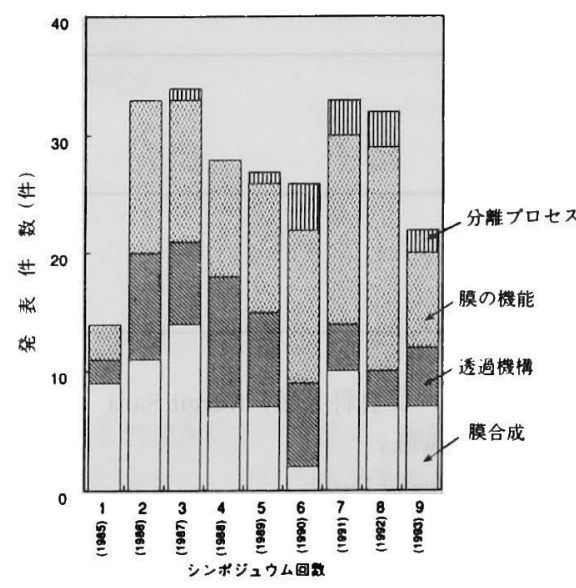

図 1 発表件数の推移

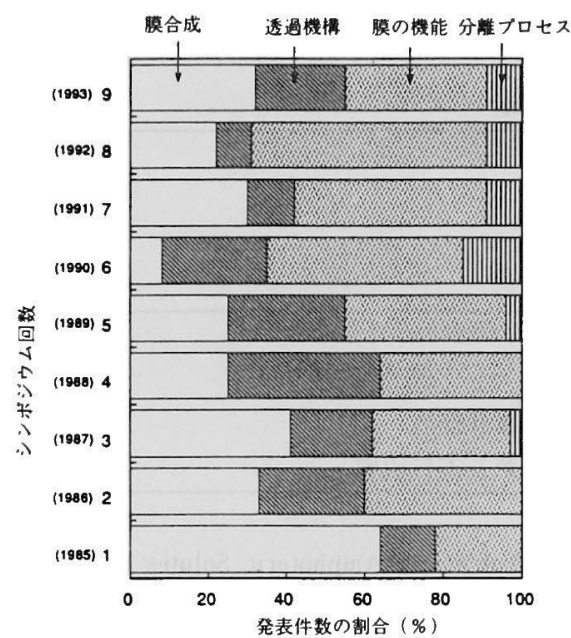

図2 発表分野の割合

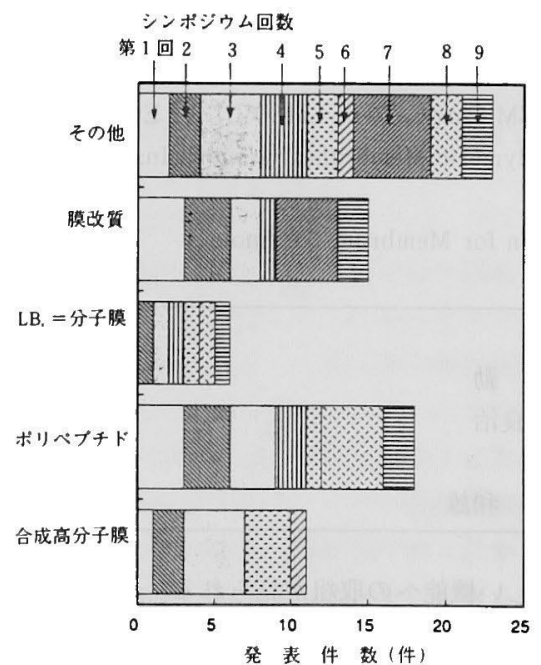

図 3 膜合成分野の発表件数

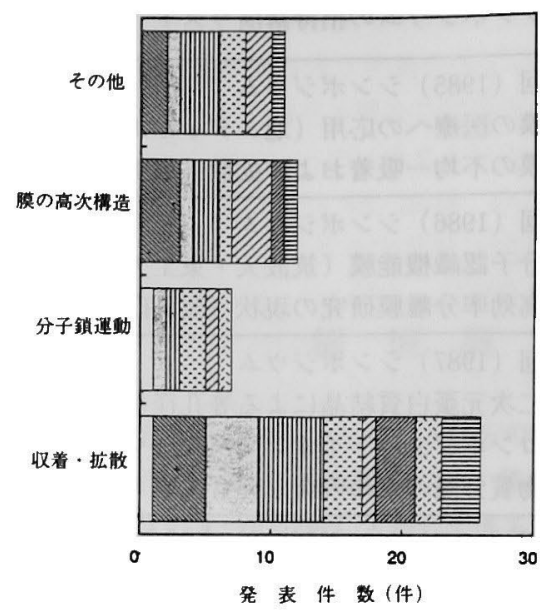

図4透過機檴分野の発表件数

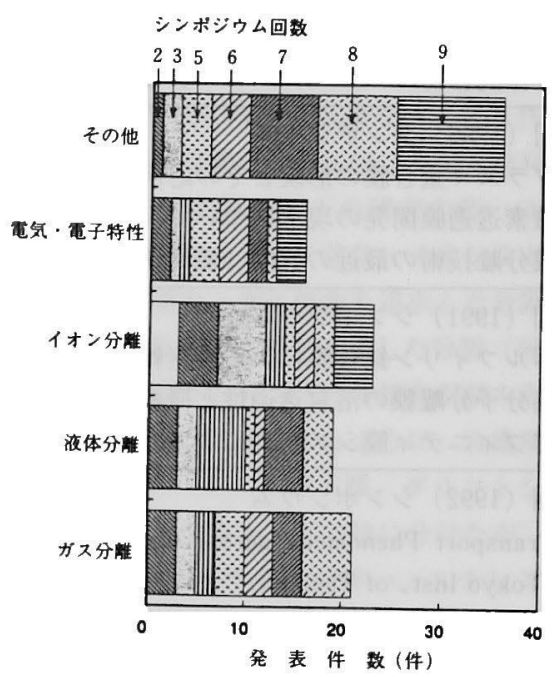

図 5 膜機能分野の発表件数

払われるまでシンポジウムに参加する研究者の関心が広 がっている。

本瀻維学会が主管する「膜一その基礎科学と技術一に 関する」シンポジウムの 9 年間の歩みを中心にまとめ た。本文でも述べたように，この 9 年間で研究の興味の 対象は単に新規な膜合成から, 機能を直接追求した膜の 創製に移っている。膜の持つ機能も分離に限定せず，電 気・電子機能にまで関心が広がっている。これはより生 体膜に近い膜を求めようとする願望であろう。今から10 年後の発展がどのようになっているかが楽しみである。 (平成 6 年 3 月 9 日受理) 